\title{
Formation of bachelors' competence readiness to work in a team
}

\section{Formación de competencias en los solteros para el trabajo en equipo}

\author{
Nadegda V. Saratovtseva \\ Penza State Technological University, Penza, Russia. \\ ORCID: https://orcid.org/0000-0002-5733-6440 \\ Olga E. Kozlova \\ Togliatti State University, Togliatti, Russia. \\ ORCID: https://orcid.org/0000-0002-3686-6725
}

\section{Olga I. Vaganova}

Minin Nizhny Novgorod State Pedagogical University, Nizhny Novgorod, Russia.

ORCID: https://orcid.org/0000-0001-8347-484X

\section{Olga T. Chernei}

Minin Nizhny Novgorod State Pedagogical University, Nizhny Novgorod, Russia.

ORCID: https://orcid.org/0000-0003-4561-9811

\section{Zhanna V. Smirnova}

Minin Nizhny Novgorod State Pedagogical University, Nizhny Novgorod, Russia.

ORCID: https://orcid.org/0000-0001-9950-9824

*Correspondence

Email: ivannovadremova29@gmail.com
Cite as:

Saratovtseva, N., Kozlova, O., Vaganova, O., Chernei,
O., Smirnova, Z. (2021). Formation of bachelors'
$\begin{aligned} & \text { competence readiness to work in a team. Propósitos y } \\ & \text { Representaciones, } 9 \text { (SPE1), e807. Doi: } \\ & \text { http://dx.doi.org/10.20511/pyr2021.v9nSPE1.807 }\end{aligned}$

(C) Universidad San Ignacio de Loyola, Vicerrectorado de Investigación, 2021. 


\section{Summary}

The purpose of the article is to analyze the experience of forming the competence of bachelors' readiness to work in a team. This competence is characterized by the ability of the student to realize their role in the team and to carry out social interaction, to focus on cooperation with team members. The requirements for training modern bachelors who are capable of continuous personal and professional growth through effective collective work are reflected in regulatory documents. In the structure of the competence of readiness to work in a team, we distinguish motivational, cognitive and functional components. Their formation is carried out in the course of studying the module "Man, society, culture", the disciplines "Fundamentals of management culture", "General psychology" and others. Where a significant role is played by the use of innovative educational technologies that contribute to building effective interaction between students. Special attention is paid to the development of such qualities of the student as sociability, openness, a sense of mutual assistance, positive emotional mood. Modern educational technologies of interaction have an active impact on the process of forming the bachelor's competencies of readiness to work in a team.

Key Words: competence, communication skills, interaction, sociability, professional training, willingness to work in a team.

\section{Resumen}

El propósito del artículo es analizar la experiencia de formar la competencia de la disposición de los solteros para trabajar en equipo. Esta competencia se caracteriza por la capacidad del alumno para darse cuenta de su rol en el equipo y llevar a cabo la interacción social, para centrarse en la cooperación con los miembros del equipo. Los requisitos para la formación de solteros modernos que sean capaces de un crecimiento personal y profesional continuo mediante un trabajo colectivo eficaz se reflejan en los documentos reglamentarios. En la estructura de la competencia de disposición para trabajar en equipo, distinguimos componentes motivacionales, cognitivos y funcionales. Su formación se lleva a cabo en el transcurso del estudio del módulo "Hombre, sociedad, cultura", las disciplinas "Fundamentos de la cultura gerencial", "Psicología general" y otras. Donde se juega un papel significativo mediante el uso de tecnologías educativas innovadoras que contribuyen a construir una interacción efectiva entre los estudiantes. Se presta especial atención al desarrollo de cualidades del estudiante como la sociabilidad, la apertura, el sentido de ayuda mutua, el estado de ánimo emocional positivo. Las tecnologías educativas modernas de interacción tienen un impacto activo en el proceso de formación de las competencias de preparación para trabajar en equipo del bachillerato.

Palabras clave: competencia, capacidad de comunicación, interacción, sociabilidad, formación profesional, disposición para trabajar en equipo.

\section{Introducción}

In modern educational conditions, the primary task is to form a person who possesses communication skills (Vaskovskaya, 2018), which allow not only individual activities, but also effective collaboration with colleagues in a team to solve complex professional tasks (Klinkov, 2018).

In the context of updating the formation of bachelor's readiness to work in a team, there is a lack of justification for this process in modern pedagogical research (Prokhorova \& Semchenko, 2018).

Special attention is paid to such qualities as individuality, sociability, independence, creativity (Oros, 2018). 
The requirements for training modern bachelors who are capable of continuous personal and professional growth reflect the Federal law" on education in the Russian Federation "from 29.12.2012 №273FZ; the national project" Education"; Federal state educational standards of higher education. The competence "working in a team" formed by students of higher educational institutions is one of the universal requirements for the results of training in higher schools (Donetskova, 2019). For example, as one of the universal competencies in the Federal state educational standard of higher education, the competence "the Ability to carry out social interaction and realize their role in the team" is designated. the Competence includes indicators: understanding the effectiveness of using the strategy of cooperation to achieve a goal, determining their role in the team; planning a sequence of steps to achieve the set results; exchanging information with other team members, making presentations of results; selecting strategies and tactics for interacting with a given category of people (Aleksieienko-Lemovska, 2019).

The idea of forming readiness to work in a team is reflected in the national doctrine of education of the Russian Federation until 2025, which notes the importance of preparing students who are ready for continuous professional improvement (Filchenkova, 2019).

This article examines the experience of developing the bachelors' competence to work in a team in higher education.

\section{Theoretical framework}

Of particular importance for our research are works that reveal the formation of students' readiness to work in a team as a necessary component of professional activity (Cirdan, 2019). Various aspects of teamwork are reflected in the works of A. G. Asmolov, Yu.a. Grachev, Yu. M. Zhukov, A. A. Rean and other scientists who studied the psychological and pedagogical theory of personality development.

The concept of "team" and "readiness to work in a team" is considered by N. F. Plotnikova, V. S. Okuneva, G. V. Lopatenkov, A. S. Moskalenko and others.

The process of interaction between students is formed during the implementation of various innovative educational technologies (Vaganova et al., 2019b). In the work of O. A. Andrienko, technologies are considered as an important component of the group activity of students (Andrienko, 2019a). The scientist also pays special attention to gaming technologies (Andrienko, 2019b).

An important role in our research is played by the work of scientists who have devoted their works to the issue of student cooperation as an effective way to develop the interaction of students in a group (Chertovskikh, 2019).

Cooperation is an interaction in which its subjects reach a mutual agreement and strive to achieve common goals (Andriushchenko, 2018). As a rule, several types of student behavior strategies appear in the process of cooperation:

- cooperation aimed at fully meeting the needs of interacting parties (Pichugina \& Zhilyakova, 2019);

- compromise-achieving the goals of both stakeholders in terms of relative equality (Pisarenko, 2019);

- avoidance, which usually negatively affects the achievement of goals, since it is a departure from contact and the loss of one's own goals in order to avoid the gain of another (Pisarenko, 2019). 
For effective cooperation, the following conditions must be met:

- encouraging all students to participate in the educational process (Kobernyk et al., 2018);

- active exchange of experience (Petrichev et al., 2018);

- joint discussion of problems and active search for solutions (Bakhareva, 2019).

All participants should be in a co-creation environment, go to a common goal together, clearly allocating roles and functions (Tsarapkina et al., 2019b). They are assigned the task of performing a task collectively based on each student's experience (Gladkov et al., 2019).

Educational collaboration encourages communication and cognitive activity. Here, awareness, reflexivity, initiative, responsibility, and mutual understanding of students begin to form (Chil Núñez et al, 2020). Among the principles of implementation of various forms of cooperation are: systematic, continuity of cognitive processes; problem-based learning; Dialogic; reflexive.

Scientists present the process of cooperation as an interaction of subjects (Raven, 2017), as a joint activity (Vaganova et al., 2019c), as the main method of interaction (Grigoriev et al., 2019), as a learning technology (Halatsyn \& Feshchuk, 2019), as a method of cooperative learning (Pliushch, 2018), as a set of conditions for managing and organizing mutual actions of teachers and students (Tolkanuk, 2019).

\section{Methodology}

9 groups of students of higher educational institutions took part in the study on the formation of teamwork competence. The total number of participants was 223. For three years $(2017,2018$, 2019), we conducted statistical data processing on the level of competence formation among second-year students. Therefore, second-year students were selected for the study (Rojas et al, 2017).

To develop the competence of readiness to work in a team, we organized interaction among students using game technologies, technologies for successful learning, technologies for learning in collaboration, project and discussion technologies. The implementation of collective activities was carried out in the course of studying the module "Man, society, culture", the disciplines "Fundamentals of management culture", "General psychology" and others. We have created criteria for the formation of readiness for work. They are shown in Table 1 in the team.

Table 1.

Evaluation criteria by an expert of a training complex (as part of our study)

\begin{tabular}{|l|l|}
\hline \multicolumn{1}{|c|}{ Criteria } & \multicolumn{1}{c|}{ Characteristic } \\
\hline Motivational & $\begin{array}{l}\text { The presence of internal motives of the student to carry out team activities with } \\
\text { classmates; awareness of the desire to develop personal qualities and the desire } \\
\text { to acquire knowledge that contributes to the development of teamwork skills, } \\
\text { the presence of developed personal qualities: balance, openness, tolerance, self- } \\
\text { control, the flexibility of thinking, stress tolerance, initiative, tolerance, social } \\
\text { activity }\end{array}$ \\
\hline Cognitive & $\begin{array}{l}\text { Student knowledge of the principles of teamwork; the ability to analyze their } \\
\text { activities and the activities of their teammates; reflection skills }\end{array}$ \\
\hline Functional & $\begin{array}{l}\text { Ability to set adequate goals, mastery of various ways of joint activities, } \\
\text { communication skills in a multicultural society }\end{array}$ \\
\hline
\end{tabular}


A high level of competence formation is characterized by the following indicators. The formation of the motivational component is characterized by the presence of deep internal motives of the student to carry out team activities with classmates, the desire to develop personal qualities and the desire to master new professional knowledge when working in a team is deliberate and conscious. The cognitive component is characterized by a confident knowledge of the principles of teamwork. The student is able to analyze their own activities and the activities of their colleagues on the team, can easily conduct reflection. The formation of a functional component reflects the ability to set adequate goals. The student skillfully operates in various ways of joint activity.

The average level of competence formation. The student is motivated to carry out team activities with classmates, has a desire to develop personal qualities and a desire to master new professional knowledge when working in a team. The student knows the principles of working in a team. Shows the ability to analyze their activities and the activities of their colleagues on the team are able to reflect. The student can set achievable goals and knows how to work together.

Low level of competence formation. The student is not motivated to carry out team activities. He has little interest in developing personal qualities to master knowledge that contributes to the development of team skills. The student is familiar with the principles of working in a team. Analyzes your activities and those of your teammates. It does not conduct reflection, but can set achievable goals, knows how to work together.

When working in a team, the student's ability to demonstrate qualities for successful implementation of team activities (for example, tolerance, goodwill, openness, non-conflict) is taken into account.

\section{Results and discussion}

The formation of competencies of readiness to work in a team is carried out on the example of such disciplines as "Fundamentals of management culture", "Man, society, culture", "General psychology".

To form these competencies, it is necessary to expand the space of team interaction (Vaganova et al., 2019a). We used game technologies, technologies of collaboration, technologies of creating success, in which students were able to form positive interpersonal relationships, communication skills without psychological stress and emotional constraint.

Integrative interaction of classroom and extracurricular activities was carried out through competitions, conferences, games, team competitions and other types of collective work.

During participation in such works, students improve such qualities as sociability, openness, and a sense of camaraderie.

The educational process was dominated by group training, when students are divided into groups of 5-7 people. They were asked to conduct a "brainstorm" to determine the direction of work. Choose the head of the subgroup and assign roles to solve such tasks as: collecting up-todate information; studying forecasts of specialists on certain issues; developing your own ideas. To protect the work, students were asked to choose a speaker or speakers who would speak on behalf of the entire team. The work based on the principle of distribution of roles and functions makes it possible for each student to become an active subject of educational activity and to become involved in the educational process.

In the process of training students, much attention was paid to the implementation of projects. Information technologies were used for interaction. The Moodle e-learning platform provides all the necessary tools for rapid task completion. Students have the opportunity to join 
groups and organize chats for each specific topic. Students develop joint projects to participate in competitions. Each student contributes to the development of the project. A general discussion of the topic can be organized via the Zoom platform. Zoom is designed for remote conferencing using cloud computing. Lectures contact and independent work are also carried out with the use of Zoom. All participants in the educational process can ask questions and actively interact while attending the electronic lesson.

In the process of organizing collective activities, technologies of cooperation are used. At the same time, the teacher creates situations of success that allow students to achieve better educational results. The joy and emotional lift from the completed work form new motives that encourage the student to study additional material. Students are involved in activities, feeling confident in their own actions. Situations of success contribute to the formation of mutual understanding between the teacher and students.

The technologies used to organize interaction between students increase motivation, stimulate high performance, develop initiative, creativity, and activity.

We conducted statistical measurements of the level of competence formation and readiness to work in a team.

The results of the statistical measurements are shown in Figure 1.

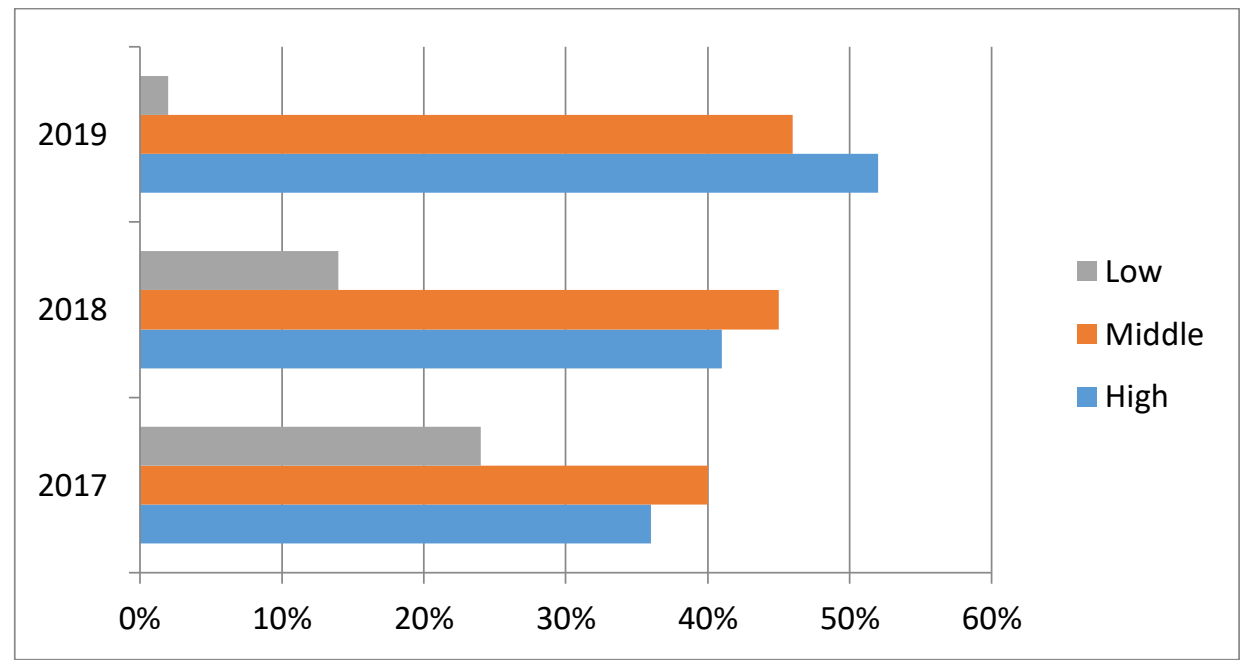

Fig. 1. Results of statistical data processing to identify the level of competence formation readiness to work in a team (as part of our study)

By 2019, the level of competence formation and readiness to work in a team has significantly increased. The number of students with a high level of formation of this competence increased from $36 \%$ to $52 \%$. For 2019 , the low level was recorded in $2 \%$ of students, which is $22 \%$ lower than in 2017.

Students have increased their interest in working in a team. Many students appreciated its advantages over individual work. During the study, the number of people who want to participate in various team professional competitions has increased, and the desire to implement their skills in a team has increased.

Figure 2 shows the results of the analysis of the number of students who participated in team professional competitions and conferences held within the higher education institution in 2017, 2018, 2019. 


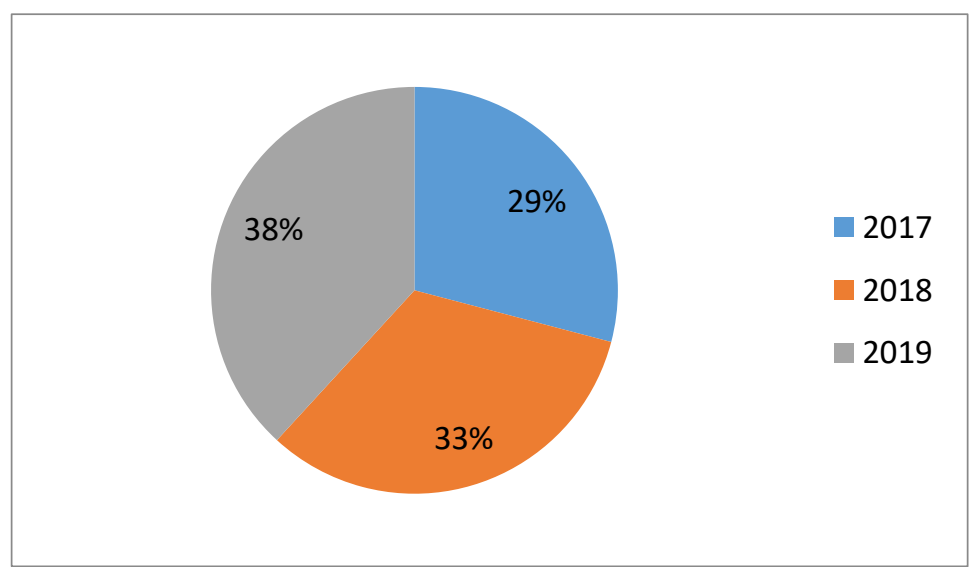

Fig. 2. The number of students who participated in professional competitions and conferences in 2017, 2018, and 2019. (as part of our study)

In 2017, of the total number of students who participated in the study, only $29 \%$ of students actively participated in various team competitions and conferences of higher education. In 2018, this percentage reached $33 \%$. In 2019, 38\%.

Based on the results obtained, we can talk about an increase in students ' readiness to work in a team.

Students began to openly and argumentatively Express their opinions, interact with all participants in the process, and respond adequately to criticism. Students began to analyze information and offer constructive solutions to specific issues. Most students have mastered the skill of effective teamwork.

\section{Conclusions}

The formation of team readiness competence is a long and multidimensional process that affects all levels of training. Modern methods, forms and technologies of organizing educational activities make this process more rapid.

The ability to work effectively in a team is one of the components of the success of future professional activities. In modern conditions, the competencies associated with working in a team form the competitiveness of a bachelor in the labor market. The paper analyzes the experience of forming the competence of bachelors' readiness to work in a team. The data obtained indicate an increase in the level of competence formation. Students are involved in active team activities. During the research, many students have become aware of this type of activity, have become more interested. While participating in such projects, students improve their communication skills, openness, and sense of camaraderie. They become able to build effective teamwork, which allows them to carry out professional activities more confidently.

Modern educational technologies of interaction have an active impact on the process of forming the bachelors' competencies of readiness to work in a team.

Conflict of interests: The authors declare that they have no conflicts of interest.

Authors' contribution: The authors have participated in the research process, in the writing of the work and in the analysis of the documents. 


\section{Bibliographic references}

Aleksieienko-Lemovska, L.V. (2019). The activity approach as a basis for preschool teachers' methodological activities. Humanitarian Balkan Research, 3, 4(6), 10-14.

Andrienko, O.A. (2019a). On the need to apply gaming training technologies. Balkan Scientific Review, 2 (4), 5-8.

Andrienko, O.A. (2019b). Modern educational technologies: technology of self-presentation. Balkan Scientific Review, 1(3), 5-7.

Andriushchenko, T. K. (2018). Personal aspects of pedagogue's innovative culture. Scientific Vector of the Balkans, 1, 13-16.

Bakharev, N. P. (2019). Creativity - a prerequisite for the formation of professional competences in specialists of technical direction of training. Scientific Vector of the Balkans, 3, 4 (6), $17-21$.

Chertovskikh, O.O. (2019). Prospects for the use of digital resources in education. Baltic Humanitarian Journal. 8, 4 (29), 184-187.

Chil Núñez, I., Escalona Arranz, J., Molina Bertrán, S., Dutok Sánchez, C., Arias Ramos, D., Pérez Rondón, L., Ochoa Pacheco, A., \& Picanço Souto, R. (2020). Perfeccionamiento de la estrategia curricular de medio ambiente de la carrera de ciencias farmacéuticas de la Universidad de Oriente, Cuba. Revista Científica Del Amazonas, 3(5), 6-17. https://revistadelamazonas.info/index.php/amazonas/article/view/24

Cirdan, A.P. (2019). Innovative technologies of professional training of future economists in the system of continuous education. Humanitarian Balkan Research, 2(4), 27-30.

Donetskova, O.YU. (2019). Modernization of the modern education system in Russia. Baltic Humanitarian Journal, 8, 2 (27), 37-39.

Filchenkova, I.F. (2019). Educational management of innovative activity of teachers as an object of pedagogical research. Minin University Bulletin (Journal of Minin University), 7(4), 3.

Gladkov, A.V., Vaganova, O.I., \& Prokhorova, M.P. (2019). Modern pedagogical technologies as a means of enhancing educational motivation. Baltic Humanitarian Journal, 8, 1 (26). 274-276.

Grigoriev, S. G., Shabunina V. A., Tsarapkina, Ju. M., \& Dunaeva N. V. (2019). Electronic library system as a means of self-development of students of digital generation $\mathrm{Z}$ (on the example of studying the course "Basics of the counselor activity"). Scientific and technical libraries, 7, 78-99. 29.

Halatsyn, K.A., \& Feshchuk, A.M. (2019). Diagnosing motivational-and-valuable component of the communicative culture of students in higher technical educational institutions. Balkan Scientific Review, 3, 2 (4), 17-20.

Klinkov, G.T. (2018). The specificity of manifestation of pedagogical communication as a special construct. Scientific Vector of the Balkans, 1, 51-52.

Kobernyk, O.M., Stetsenko, N.M., Boichenko, V.V., \& Pryshchepa, S.M. (2018). Improving professional and pedagogical training of future teachers by moodle platforms (On the example of the course "Pedagogy"). Scientific Vector of the Balkans, 1, 5-7. 
Oros, I.I. (2018) The role of international connections in the development of the adult education system. Humanitarian Balkan Research, 1, 57-59.

Osadchenko, I.I. (2019). Key concepts of situational training technology in preparing future teachers. Scientific Vector of the Balkans, 1 (3), 46-49.

Petrichev, P. V., Masyuk, N. N., \& Bushueva, M. A. (2018). Method of estimation of the effectiveness of the partnership russian universities with foreign educational organizations. Research Azimuth (Azimuth of Scientific Researches: Economics and Management), 7, 3 (24), 229-232.

Pichugina, G. A., \& Zhilyakova, D. A. (2019) Structuring the organization of the process of creativity. Scientific Vector of the Balkans, 3, 3 (5), 55-58.

Pisarenko, D. A. (2019). Evaluation of extracurricular activities of university students with a competency-based approach. Scientific Vector of the Balkans, 3, 3 (5), 37-40.

Pliushch, V.M. (2018). Independent work of students as a factor of improving education quality. Balkan Scientific Review, 1, 69-71.

Prokhorova, M.P., \& Semchenko, A.A. (2018). Involving of trainees-future teachers of professional training in project activities in the discipline. Minin University Bulletin (Vestnik of Minin University), 6(2), 6.

Raven, J. (2017). Education and Sociocybernetics. Research Azimuth (Azimuth of Scientific Researches: Economics and Management), 6, 3 (20), 289-297.

Rojas, M.J., López de Parra, M.L., Arbeláez, D.F., y Correa, L. (2017). "Rendimiento académico en estudiantes de secundaria según asignaturas, estrato socioeconómico y su contacto con el conflicto armado en Colombia" Revista Latinoamericana de Estudios Educativos, XLVII (3-4), 155-172. https://www.redalyc.org/pdf/270/27054113006.pdf

Tolkanuk, Z. A. (2019). Professional self-determination of youth as a factor of training of a competent specialist. Balkan Scientific Review, 3, 2 (4), 57-59.

Tsarapkina, Ju. M., Dunaeva, N. V., \& Kireicheva, A. M. (2019b). Application of BYOD technology in education on the example of Lecture Racing mobile application, Computer Science and Education. Informatics and Education, 9(308), 56-64.

Tsarapkina, Ju.M., Petrova, M.M., Mironov, A.G., Morozova, I.M., \& Shustova, O.B. (2019a). Robotics as a basis for Informatization of education in children's health camp. Amazonia $\begin{array}{llll}\text { Investiga, } & 8 & \text { 115-123. }\end{array}$ https://www.amazoniainvestiga.info/index.php/amazonia/article/view/70

Vaganova, O.I., Ilyashenko, L.I., Smirnova, Zh.V., Bystrova, N.V., \& Kaznacheeva, S.N. (2019a). Students' creative abilities development in higher educational institution. Amazonia Investiga, $8(22)$, 701-710. https://www.amazoniainvestiga.info/index.php/amazonia/article/view/822

Vaganova, O.I., Rudenko, I.V., Markova, S.M., Smirnova, Zh.V., \& Kutepov, M.M. (2019b). The use of educational video materials in educational process of a higher educational institution. Amazonia Investiga, 8(22), 216-222. https://www.amazoniainvestiga.info/index.php/amazonia/article/view/308 
Vaganova, O.I., Livshits, Yu.A., Aleshugina, E.A., Smirnova, Zh.V., \& Kutepova, L.I. (2019c). Experience in developing electronic glossary in a higher education institution. Amazonia Investiga, $8(22)$, $247-253$ https://www.amazoniainvestiga.info/index.php/amazonia/article/view/421

Vaskovskaya, G.A. (2018). Features of implementation of pedagogical technologies of profile training. Balkan Scientific Review, 1, 76-79. 